\title{
Ewa Leniart
}

Uniwersytet Rzeszowski e-mail: ewaleni@interia.pl telefon: +48178721528

DOI: $10.15290 /$ mhi.2015.14.01.21

\section{Odpowiedzialność karna funkcjonariuszy komunistycznego państwa za zbrodnie komunistyczne}

\author{
SUMMARY \\ Criminal Liability of Officers of the Communist State for Communist Felonies
}

Accounting for criminal acts committed by the communist Polish state and its officers requires establishing the principles of their responsibility. An act passed by the Sejm of the Republic of Poland delivered legal grounds to this responsibility from 18 December 1998, concerning the Institute of National Memory - a committee for pursuing cases of felony against the Polish nation. The provisions of this act enable officers of the former communist regime, which conducted criminal proceedings in matters having a political base, to be brought to justice. Judging and sentencing the civil servants responsible for bending the law to realise the political objectives of the Polish United Workers' Party and communist authorities,constitutes a just and appropriate way of dealing with these past events. Complementing justice in this respect should be a warning to future generations that immorality and injustice will always be subject to retribution.

Key words: criminal liability, criminal law, officers of the communist state, communist felonies

Słowa kluczowe: odpowiedzialność karna, prawo karne, funkcjonariusze komunistycznego aparatu, zbrodnie komunistyczne

Podstawę prawną do pociągnięcia do odpowiedzialności karnej funkcjonariuszy komunistycznego państwa dostarczyła uchwalona przez Sejm RP ustawa o Instytucie Pamięci Narodowej - Komisji Ścigania Zbrodni przeciwko Narodowi Polskiemuํ. Przepisy tejże ustawy umożliwiają pociągnięcie do odpowiedzialności karnej m.in. funkcjonariuszy państwa komunistycznego, którzy prowadzili postępowania karne w sprawach, mających polityczne podłoże. Do

1 Ustawa z dnia 18 grudnia 1998 r. o Instytucie Pamięci Narodowej - Komisji Ścigania Zbrodni przeciwko Narodowi Polskiemu (t.j. 2014, poz. 1075). 
uznania, iż w postępowaniu karnym miał miejsce czyn, który był zbrodnią komunistyczną, niezbędne jest ustalenie, iż czyn ten spełniał warunki określone w art. 2 ust. 1 ustawy o Instytucie Pamięci Narodowej².

Dla postawienia zarzutu popełnienia zbrodni komunistycznej konieczne jest udowodnienie, że działania funkcjonariusza publicznego stanowiły przestępstwo w świetle przepisów polskiej ustawy karnej obowiązującej w czasie ich popełnienia ${ }^{3}$. Czynności tego rodzaju powinny stanowić formę represji dokonaną przez funkcjonariusza komunistycznego państwa ${ }^{4}$ wobec jednostki lub grup ludności z powodu rzeczywistej lub domniemanej działalności i mogły być formą prześladowania za „działalność niezgodną z obowiązującą wówczas linią polityczną" ${ }^{5}$. Jednocześnie podkreślić należy, że do uznania określonego przestępstwa za zbrodnię komunistyczną nie jest niezbędne udowodnienie, iż sprawca działał z motywów politycznych lub z powodu preferowania przez niego określonej ideologii społeczno-politycznej ${ }^{6}$.

Za zbrodnię komunistyczną może być uznane aresztowanie, prowadzenie śledztwa, sporządzenie aktu oskarżenia lub wydanie wyroku dokonane przez konkretnego funkcjonariusza komunistycznego państwa - bezprawne w świetle przepisów ustawy obowiązującej w czasie popełnienia czynu ${ }^{7}$ Ponadto, musi zostać udowodnione, iż w związku z piastowaną funkcją doszło do prze-

2 Zdaniem Roberta Kopydłowskiego, zbrodnie komunistyczne obejmują cztery kategorie zachowań: czyny polegające na stosowaniu represji wobec jednostek lub grup ludności, czyny polegające na stosowaniu wobec jednostek lub grup ludności innych niż represje form naruszania praw człowieka, czyny pozostające $\mathrm{w}$ związku ze stosowaniem represji oraz czyny pozostające $\mathrm{w}$ związku ze stosowaniem innych form naruszania praw człowieka. Więcej zob. R. Kopydłowski, Analiza definicji zbrodni komunistycznej, [w:] Zbrodnie przesztości. Opracowania i materiały prokuratorów IPN, t. 4, Ściganie, red. R. Ignatiew, A. Kura, Warszawa 2012, s. 22.

3 Oznacza to, że czyn musiał być zabroniony przez ustawę obowiązującą w czasie jego popełnienia pod groźbą kary, społeczna szkodliwość czynu musiała być wyższa niż znikoma, a sprawcy można było przypisać winę w czasie czynu. Więcej zob. Postanowienie SN z 5 VII 2005, sygn. akt WZ 13/05, OSNKW 2005/10/98; L. Rączy, Zbrodnie sq̨dowe sędziów i prokuratorów - wybrane zagadnienia odpowiedzialności karnej na podstawie ustawy o Instytucie Pamięci Narodowej - Komisji Ścigania Zbrodni przeciwko Narodowi Polskiemu, [w:] Zbrodnie przeszłości. Opracowania i materiały prokuratorów IPN, red. P. Piątek, t. 9, Warszawa 2006, s. 7.

4 Funkcjonariuszem komunistycznego państwa był funkcjonariusz publiczny, a także każda osoba, która podlegała ochronie jako funkcjonariusz publiczny oraz sędzia i prokurator. Więcej zob. P. Piątek, Glosa do wyroku Sadu Apelacyjnego w Katowicach z dnia 28 lutego 2003 roku, sygn. akt II Aka 298/02 (dotyczy pojęcia zbrodni komunistycznej), [w:] Zbrodnie przeszłości. Opracowania..., s. 26; L. Rączy, op. cit., s. 7; Uzasadnienie wyroku Sądu Apelacyjnego w Warszawie z 10 II 2005 r. sygn. akt II Aka 440/04, OSA 2005/9/67, LEX 146670.

5 Wyrok SA w Warszawie z 10 II 2005 r., sygn. akt II Aka 440/04, cyt. za: R. Kopydłowski, op. cit., s. 22.

6 W tej sprawie w orzecznictwie można odnaleźć sprzeczne stanowiska. Por. Wyrok Sądu Apelacyjnego w Katowicach z 28 II 2003 r., sygn. akt II Aka 298/02, KZS 2006/11/97, LEX 228004; Wyrok Sądu Apelacyjnego w Warszawie z 10 II 2005 r., sygn. akt II Aka 440/04, OSA 2005/9/67, LEX 146670 .

7 L. Rączy, op. cit., s. 11. 
kroczenia uprawnień lub niedopełnienia obowiązków przez tego funkcjonariu$\mathrm{sza}^{8}$, a czyn taki mógł stanowić przestępstwo w momencie jego popełnienia.

Zakres uprawnień i obowiązków sędziów i prokuratorów wojskowych regulowały przepisy art. 3 kodeksu wojskowego postępowania karnego ${ }^{9}$, art. 1 prawa o ustroju sądów wojskowych i prokuratury wojskowej ${ }^{10}$ i 51 prawa o ustroju sądów wojskowych i prokuratury wojskowej ${ }^{11}$. Przekroczenie uprawnień lub niedopełnienie obowiązków np. przez sędziego mogło doprowadzić do utraty życia lub długotrwałego pozbawienia wolności oskarżonego, a następnie skazanego ${ }^{12}$.

Pociągnięcie do odpowiedzialności karnej za zbrodnię komunistyczną wymaga dowiedzenia umyślności w działaniu sprawcy. Konieczne jest udowodnienie, że sędzia działał $\mathrm{w}$ zamiarze stosowania represji ${ }^{13}$ wobec przeciwników politycznych ${ }^{14}$. Ponadto należy udowodnić, że posługiwał się przepisami prawa instrumentalnie, wykorzystując je jako narzędzie do rozprawienia się z obywatelami, w których rozpoznał politycznych przeciwników władzy. Dopiero udowodnienie takiego charakteru działań może być podstawą do odpowiedzialności karnej funkcjonariusza komunistycznego państwa, który przekraczając swe uprawnienia lub nie dopełniając swych obowiązków, działał na szkodę dobra publicznego lub prawnego ${ }^{15}$.

8

9 nego czynu, wyjścia poza semantyczną treść przepisu w celu pociągnięcia do odpowiedzialności karnej, wymierzenia kary niewspółmiernej do udowodnionego czynu, wydania wyroku po śledztwie prowadzonym z naruszeniem praw człowieka, gdy skazanie nastąpiło na podstawie fałszywych dowodów, niezweryfikowanych w procesie oraz każdego innego aktu bezprawia dokonanego przez sędziego. Więcej zob. W. Kulesza, Odpowiedzialność karna sędziów i prokuratorów za zbrodnię sądowa, [w:] Przestępstwa sędziów i prokuratorów w Polsce w latach 1944-1956, red. W. Kulesza, A. Rzepliński, Warszawa 2000, s. 510-512.

13 W orzecznictwie zostało zdefiniowane także pojęcie represji jako wszelkich form prześladowania będących następstwem działalności na rzecz niepodległego bytu państwa polskiego. Formy prześladowania mogły polegać m.in. na niesłusznym zatrzymaniu, ale także niesłusznym skazaniu, np. na karę pozbawienia wolności. Zob. Wyrok Sądu Apelacyjnego w Warszawie z 10 II 2005 r., sygn. akt II AKa 440/04, OSA 2005/9/67, LEX 146670.

R. Kopydłowski, op. cit., s. 23.

Art. 231 §1 kodeksu karnego z dnia 6 czerwca 1997 r. (Dz.U. 1997, Nr 88, poz. 553 z późn. zm.) (dalej k.k.) i art. 189 §2 k.k. w związku z art. 11 §2 k.k. 
Rozważając zagadnienie pociągnięcia do odpowiedzialności karnej sędziów w związku z naruszeniem przez nich prawa przy wydaniu wyroków, należy pamiętać o udziale $w$ składach orzekających ławników ${ }^{16}$. Udział ławników w wydaniu wyroków miał inny charakter niż działalność sędziów.

Zarzut formułowany wobec ławników może dotyczyć przekroczenia uprawnień związanych z orzekaniem. Skutkować to może wnioskiem, że będąc w składzie orzekającym WSR w Rzeszowie, wbrew zebranym w sprawie dowodom dopuścili się dowolności $\mathrm{w}$ ocenie prawnej zachowania oskarżonego. Za pociągnięciem ławników do odpowiedzialności karnej przemawia to, iż ławnik na równi z sędzią uczestniczył w wydaniu wyroku, a głos ławnika jako członka składu orzekającego, miał takie samo znaczenie i skutki jak głos sędziego.

W praktyce pociągnięcie do odpowiedzialności karnej członków składów orzekających jest niezwykle trudne. $W$ orzecznictwie prezentowany jest pogląd, iż "działalność członków składów orzekających nie zawierała cech bezprawności, albowiem jako członkowie składu orzekającego mieli oni prawo do wydawania wyroków [...] a w konsekwencji do wymierzania kary"17.

Pociągnięcie do odpowiedzialności karnej członków składu orzekającego staje się możliwe dopiero wtedy, gdy zostanie udowodnione, iż w konkretnym przypadku doszło do przekroczenia uprawnień, a w konsekwencji członek składu orzekającego wydał wyrok wbrew zebranym w sprawie dowodom, czyli dopuścił się częściowej lub całkowitej dowolności w ocenie prawnej postępowania oskarżonego. Wówczas wydany wyrok może zostać uznany za formę represji politycznej „za ujawnienie [...] poglądów niechętnych wobec ustroju komunistycznego oraz podporządkowaniu Polski Związkowi Radzieckiemu"18.

Sędziowie, którzy wydając wyroki, naruszyli zasadę niezawisłości sędziowskiej ${ }^{19}$, mogą także zostać pociągnięci do odpowiedzialności dyscyplinarnejej ${ }^{20}$.

16 Udział ławników w sądownictwie wojskowym został przewidziany na podstawie art. 18 prawa o ustroju sądów wojskowych i prokuratury wojskowej (Dekret PKWN z 23 IX 1944 r., Dz.U. 1944, $\mathrm{Nr} 6$, poz. 29).

Wyrok WSG we Wrocławiu z 14 X 2002 r. w sprawie przeciwko Jerzemu M., sygn. akt Sg 666/01, nieopublikowany, cyt. za: L. Rączy, op. cit., s. 13.

18 Uzasadnienie wyroku Sądu Garnizonowego w Warszawie z 18 IV 2003 r. w sprawie przeciwko Tadeuszowi W., sygn. akt 477/2002, nieopublikowany, cyt. za: ibidem, s. 15.

19 Niezawisłość sędziowska powinna być cechą osobistą, charakteryzującą sędziów, która polega na tym, iż sędzia zachowuje pełną wewnętrzną samodzielność $\mathrm{w}$ ocenie faktów będących przedmiotem rozpoznania i osób występujących w różnych rolach procesowych. Sędzia powinien być bezstronny, działać bez uprzedzeń i z góry powziętych sądów. Nie powinien też ulegać żadnym wpływom zewnętrznym. Więcej zob. D. Wituszko, Wplyw immunitetu na odpowiedzialność karna sędziów i prokuratorów za zbrodnie sądowe z uwzględnieniem aspektów praktycznych wynikajacych z prowadzonych postępowań, [w:] Zbrodnie przeszłości. Studia..., s. 50.

20 E.L. Wędrychowska, Stabilność zawodu sędziego w świetle ostatnich zmian przepisów prawa o ustroju sądów powszechnych, „Prokuratura i Prawo” 2000, nr 1 (89), LEX 24022/1. 
Jej podstawą są przepisy ustawy z dnia 3 grudnia 1998 r. o odpowiedzialności dyscyplinarnej sędziów, którzy w latach 1944-1989 sprzeniewierzyli się niezawisłości sędziowskiej ${ }^{21}$. Artykuł 1 ust. 1 tej ustawy stanowi, iż do 31 grudnia 2002 r. nie stosuje się przepisów o przedawnieniu w postępowaniu dyscyplinarnym dotyczącym sędziów, którzy w latach 1944-1989, orzekając w procesach będących formą represji za działalność niepodległościową, polityczną, obronę praw człowieka lub korzystanie z podstawowych praw człowieka, sprzeniewierzyli się niezawisłości sędziowskiej. Wobec sędziów, którzy dopuścili się przedmiotowych naruszeń, sąd dyscyplinarny może orzec karę wydalenia ze służby sędziowskiej22. W 1999 r. Krajowa Rada Sądownictwa pozbawiła w trybie przewidzianym w przedmiotowej ustawie przywilejów emerytalnych dziewięciu sędziów ${ }^{23}$.

Procesów karnych nie byłoby bez udziału prokuratorów. Jego zadaniem był nadzór nad postępowaniem przygotowawczym ${ }^{24}$, zatwierdzenie aktu oskarżenia ${ }^{25}$, oskarżanie w procesie sądowym i ewentualnie złożenie skargi rewizyjnej. Rolą prokuratora w postępowaniu karnym było zatem wykonywanie czynności poznawczych, których celem było ujawnienie i zbadanie naruszeń prawa, ustalenie osób, które się ich dopuściły, i dążenie do ich ukarania ${ }^{26}$.

Nadzór nad postępowaniem przygotowawczym sprowadzał się do czuwania, by postępowanie nie spełzło na niczym ${ }^{27}$, ale także - przynajmniej $\mathrm{w}$ teorii - by nie doprowadziło do skazania osoby niewinnej ${ }^{28}$. Nie zwalnia to prokuratorów od odpowiedzialności za wyroki wydane z naruszeniem prawa dla

21 w obecności prokuratora wojskowego, potwierdzało to ważność tego dokumentu, „gdyż poziom
etyczny wojskowej prokuratury jest [...] bezsporny" (Skazani na karę śmierci przez WSR w Rzeszowie w obecności prokuratora wojskowego, potwierdzało to ważność tego dokumentu, „gdyż poziom
etyczny wojskowej prokuratury jest [...] bezsporny" (Skazani na karę śmierci przez WSR w Rzeszowie 1946-1954, red. T. Bereza, P. Chmielowiec, Rzeszów 2004, s. 20).

Dz.U. 1999, Nr 1, poz. 1 z późn. zm.

Art. 3 ustawy z dnia 3 grudnia 1998 r. o odpowiedzialności dyscyplinarnej sędziów, którzy w latach 1944-1989 sprzeniewierzyli się niezawisłości sędziowskiej.

K. Szwagrzyk, Prawnicy czasu bezprawia. Sędziowie i prokuratorzy wojskowi w Polsce 1944-1956, Kraków-Wrocław 2005, s. 251.

Nadzór prokuratorski nad postępowaniem przygotowawczym stanowił rękojmię przestrzegania „rewolucyjnej i ludowej praworządności”. Celem owej praworządności było „zdławienie zorganizowanej i popieranej od zewnątrz przez imperialistów burżuazyjno-obszarniczej kontrrewolucji, zmierzającej bezpośrednio do restauracji starego porządku". Więcej zob. J. Feldman, Nadzór prokuratora wojskowego nad postępowaniem przygotowawczym, „Wojskowy Przegląd Prawniczy” 1954, R. 27, nr 3 (39), s. 211.

25 Akt oskarżenia zakreślał podmiotowe i przedmiotowe granice postępowania karnego. Zatwierdzenie aktu oskarżenia przez prokuratora nadawało mu moc obowiązującą. Oznaczało to, iż prokurator ponosił odpowiedzialność nie tylko za konkluzję, lecz za całość aktu oskarżenia. Dodatkowo przyjmowano, że ponieważ akt oskarżenia miał zostać odczytany na rozprawie, powinien spełniać rolę wychowawczą. W tym celu osnowa aktu oskarżenia najczęściej wzbogacona była opisem ideologicznym. Więcej zob.: ibidem, s. 245.

Ibidem, s. 219.

W myśl okólnika nr 26 z 30 X 1946 r. DSS MON, jeśli przyznanie się do winy oskarżonego nastąpiło J. Feldman, op. cit., s. 219. 
osiągnięcia celu politycznego. Prokuratorowi, który występował w sprawach o podłożu politycznym w charakterze oskarżyciela publicznego, może zostać postawiony zarzut popełnienia zbrodni komunistycznej polegającej na podżeganiu do popełnienia przestępstwa zabójstwa lub pozbawienia wolności. Przy tym, pomocnictwo prokuratora miałoby polegać na dostarczaniu informacji dla składu sędziowskiego.

Początkowo zarzutem, który był stawiany prokuratorowi było współsprawstwo zbrodni sądowej29. Obecnie sądy prezentują jednak pogląd, iż oskarżenie prokuratora o zbrodnię sądową jest możliwe jedynie „pod warunkiem przedstawienia dowodów wskazujących, iż sprawca wyczerpał swym zachowaniem wszystkie znamiona zarzucanego mu czynu", a "zamiarem występującego w sprawie prokuratora nie było postawienie wniosku o wymierzenie kary [...], lecz nakłanianie sądu do [...] zabójstwa. Ta ostatnia sytuacja mogłaby zachodzić wtedy, gdyby na poparcie zarzucanego oskarżonemu przestępstwa nie było żadnego dowodu lub gdyby dowody w sprawie zostały sfałszowane i okoliczności te wiadome były prokuratorowi i sądowi"30. W praktyce oznacza to niemożliwość pociągnięcia do odpowiedzialności karnej prokuratorów oskarżających $\mathrm{w}$ sprawach o podłożu politycznym, jeżeli nawet $\mathrm{w}$ sprawach tego rodzaju dochodziło do naruszenia przepisów prawa.

Podobnie jak w przypadku sędziów sądów wojskowych prokuratorami wojskowymi nie zostawały osoby przypadkowe, a jedynie ci, którzy reprezentowali odpowiedni poziom uświadomienia politycznego ${ }^{31}$. Prokuratorzy wojskowi m.in. konsultowali z pierwszym sekretarzem KW PPR, a następnie PZPR czynności w prowadzonych i nadzorowanych postępowaniach karnych m.in. w zakresie celowości i trybu prowadzenia postępowania karnego, a nawet wymiaru kary, o który wnioskowali ${ }^{32}$.

Trzecią grupą funkcjonariuszy komunistycznych uczestniczących w sprawach o zbrodnie zdrady stanu byli funkcjonariusze śledczy Urzędu Bezpieczeństwa ${ }^{33}$. Ich zadaniem było przeprowadzenie postępowania przygotowaw-

Współsprawstwo to wnoszenie istotnego wkładu w dokonanie przestępstwa, którym było zarówno formułowanie aktu oskarżenia, jak i żądanie kary.

30 Wyrok SN Izba Wojskowa z 2 IV 2001 r. w sprawie Wacława K, sygn. akt WA 7/01, nieopublikowany, cyt. za: L. Rączy, op. cit., s. 14.

31 K. Szwagrzyk, op. cit., s. 75. Potwierdzał to Józef Feldman, podkreślając, iż „nowa kadra prokuratorska wykuwała się i hartowała w ogniu walk z wrogiem klasowym". Więcej zob. J. Feldman, op. cit., s. 212.

Więcej zob.: K. Szwagrzyk, op. cit., s. 75.

Udział funkcjonariuszy UB w sprawach politycznych o zbrodnie zdrady stanu wynikał z faktu, iż zasadniczym zadaniem organów bezpieczeństwa w Polsce było przeciwdziałanie oraz likwidacja podziemia zbrojnego i politycznego. Więcej o celach działalności UB zob. Z. Nawrocki, Zamiast wolności. UB na Rzeszowszczyźnie 1944-1949, Rzeszów 1998, s. 59 i n. Jednym ze sposobów osiągnięcia tego celu było prowadzenie postępowań karnych przeciwko członkom podziemia m.in. w sprawach, w których zarzucano popełnienie zbrodni z art. 86 k.k. WP. O prowadzeniu postępowań 
czego $^{34}$, zgromadzenie materiału dowodowego i sporządzenie aktu oskarżenia $^{35}$. Bez wątpienia osiągnięcie celu, jakim była eliminacja z życia publicznego przeciwników politycznych, było możliwe jedynie przy założeniu ścisłego i harmonijnego współdziałania prokuratorów z organami bezpieczeństwa publicznego ${ }^{36}$. O wadze pracy oficera śledczego ${ }^{37}$ może świadczyć teza propagowana wśród funkcjonariuszy komunistycznego państwa, iż nie było przestępstwa bez śladów mogących doprowadzić do ujęcia sprawcy, a tylko od umiejętności prowadzącego śledztwo i od jego zdolności zależało, czy ślad ten zostanie wykryty i należycie wykorzystany ${ }^{38}$. Praca oficera śledczego podlegała kontroli instancyjnej, ponieważ akt oskarżenia wymagał zatwierdzenia w Wydziale Śledczym WUBP przed jego skierowaniem wraz z aktami sprawy do Wojskowej Prokuratury Rejonowej ${ }^{39}$.

przygotowawczych przez organy bezpieczeństwa, jeśli postępowanie to nie zostało wszczęte przez prokuraturę wojskową, stanowił dekret o przestępstwach szczególnie niebezpiecznych w okresie odbudowy państwa polskiego z 1945 r. Zakres praw i obowiązków oficera śledczego regulował kodeks postępowania karnego z 1938 r. (Dz.U. RP 1939, Nr 8, poz. 44). Brakowało jednak szczegółowych zasad regulujących działalność oficerów śledczych UB, o czym we wspomnieniach pisał m.in. Adam Humer. Zob. Z. Leszczyńska, Procesy sądowe w latach 1944-1956 wobec członków organizacji niepodległościowych na Lubelszczyźnie, [w:] Przestępstwa sędziów i prokuratorów w Polsce..., s. 137. $\mathrm{Z}$ tego powodu prokuratura opracowała dla oficerów śledczych instrukcje o zasadach i sposobie prowadzenia postępowania przygotowawczego. W podobny sposób zostały opracowane wzory protokołów i postanowień.

34 Powierzenie funkcjonariuszom UB i Informacji Wojskowej śledztwa uzasadniane było ich fachowością, która miała rzekomo gwarantować wysoką wartość merytoryczną ich pracy. Podkreślić należy, iż oficer śledczy był traktowany jak organ prokuratury w zakresie prowadzonego postępowania przygotowawczego. Więcej zob. M. Muszkat, H. Zapolski-Downar, Podstawowe zasady kodeksu wojskowego postępowania karnego, „Wojskowy Przegląd Prawniczy” 1945, nr 1, s. 144.

Uzasadnieniem sporządzania aktu oskarżenia dla prokuratora przez oficera śledczego było to, iż jako prowadzący śledztwo znał sprawę, a zatem sporządzenie przez niego aktu oskarżenia nie wymagało dodatkowego nakładu pracy (ibidem, s. 145).

36 A. Drogoń, Prokuratura w okresie kształtowania ustroju po II wojnie światowej w Polsce (1944-1956), [w:] Wielokulturowość polskiego pogranicza. Ludzie - idee - prawo, red. A. Lityński, P. Fiedorczyk, Białystok 2003, s. 833.

37 Początkowy okres funkcjonowania pionu śledczego rzeszowskiego UBP tak opisywał pierwszy kierownik sekcji śledczej WUBP w Rzeszowie Bolesław Martiuk: „Przede wszystkim trzeba było ustalić, kto i za co został osadzony w więzieniu. Żadnej ewidencji nie mieliśmy. W powojennym chaosie tylko w odniesieniu do nielicznych przypadków sporządzano notatki na okoliczność zatrzymania. Nie było akt spraw. Wyznaczyłam jednego pracownika - Mariana Zwolańskiego, którego zadaniem było sporządzenie wykazu osób zatrzymanych $\mathrm{w}$ więzieniu, ustalenie daty zatrzymania oraz przez kogo i za co zostali zatrzymani. Zwolański, chodząc w asyście naczelnika więzienia od celi do celi, w oparciu o wypowiedzi zatrzymanych wykaz taki sporządził. Mieliśmy jakąś podstawę do dalszej pracy. Przez okres następnych trzech tygodni każdy z oficerów śledczych ustalał $\mathrm{w}$ toku przesłuchań podstawę zatrzymania. [...] Pracowaliśmy wówczas dniami i nocami" (cyt. za: Z. Nawrocki, op. cit., s. 63).

39 T. Balbus, Z. Nawrocki, Ludzie Różańskiego. Pion śledczy rzeszowskiego UB w 1948 roku, „Studia Rzeszowskie" 2002, t. 9, s. 162 
Funkcjonariusze lokalnych $\mathrm{UB}^{40}$ stanowili najliczniejszą grupę funkcjonariuszy komunistycznych, przeciwko którym skierowano akty oskarżenia ${ }^{41}$. Stawiane im zarzuty dotyczyły stosowania niedozwolonych metod w śledztwie, a także bezprawnego pozbawienia wolności.

W sprawach o podłożu politycznym dochodziło do nadinterpretacji prawa zarówno na etapie postępowania przygotowawczego, gdy sporządzano akty oskarżenia, jak i na etapie wyrokowania. Bez wątpienia celem tak prowadzonego postępowania karnego było doprowadzenie do wydania wyroku skazującego, jak uzasadniano - $\mathrm{w}$ celu "obrony demokratycznego ładu prawnego" ${ }^{\prime 2}$. Mogło się zdarzyć, że postępowanie karne miało doprowadzić do usunięcia z życia publicznego oponentów politycznych, którzy nie chcieli zaakceptować sposobu i faktu przejęcia władzy przez komunistów w Polsce po $1944 \mathrm{r}^{43}$

Obecny wymiar sprawiedliwości stanął na stanowisku, iż motywy działania sędziów i innych funkcjonariuszy komunistycznego państwa nie przesądzają o zasadności ich odpowiedzialności karnej za zbrodnie komunistyczne ${ }^{44}$. W literaturze prezentowany jest jednak także pogląd odmienny, oparty na tezie, że zbrodniami komunistycznymi były tylko takie czyny, które da się zakwalifikować jako rodzaj odwetu politycznego ${ }^{45}$.

Bez wątpienia funkcjonariusze komunistycznego państwa utożsamiali się z komunistycznym ustrojem państwa. Dawało im to poczucie bezpieczeństwa i było źródłem przekonania, że ich działania są prawnie usprawiedliwione ${ }^{46}$. Udowodnienie, że prowadzenie postępowania karnego przeciwko konkretnej osobie miało jedynie podłoże polityczne i służyło utrwalaniu ustroju totalitarnego ${ }^{47}$, nie jest jednak łatwe.

40 Wykaz oficerów śledczych WUBP i PUBP województwa rzeszowskiego za okres od 1 I 1948 do 1 I 1949 r. zob. ibidem, s. 144-155.

41 Uzasadnieniem dla tego stanu rzeczy pozostaje twierdzenie, iż „unieszkodliwienie reakcyjnych wrogów państwa, narodu i demokracji pozostanie historyczną zasługą władz bezpieczeństwa publicznego" (Rozkaz specjalny nr 5 dyrektora Departamentu Więziennictwa z 21 II 1948 r., cyt. za: K. Bedyński, Sądowa represja o charakterze politycznym wobec funkcjonariuszy więziennych w latach 1944-1956, [w:] Przestępstwa sędziów i prokuratorów w Polsce..., s. 364).

Cyt. za: L. Rączy, op. cit., s. 11.

43 Parafrazując uzasadnienie jednego z wyroków norymberskich, można przyjąć, że działalność funkcjonariuszy komunistycznego państwa uczestniczących w doprowadzeniu do skazania osób za przestępstwa $\mathrm{z}$ art. $86 \mathrm{kkWP}$ należałoby uznać za świadomy współudział w urzeczywistnianiu polityki partii komunistycznej i komunistycznego państwa w zbrodni przeciwko swym obywatelom. Więcej zob. W. Kulesza, op. cit., s. 508.

R. Kopydłowski, Pojęcie zbrodni komunistycznej z uwzględnieniem problemu czynu zabronionego popetnionego przez funkcjonariusza państwa komunistycznego, niemotywowanego szczególnym zamiarem, $n$. represji z motywów politycznych (artykuł polemiczny), [w:] Zbrodnie przeszłości. Opracowania..., s. 33-34. Ibidem. 
Niewątpliwie szczególną rolę $\mathrm{w}$ zakresie eliminacji przeciwników politycznych odegrały wojskowe sądy i prokuratury działające do $1956 \mathrm{r}$. Utworzenie sądów wojskowych i intensyfikacja ich działalności nastąpiła w związku z nieskutecznością działań podjętych wobec przeciwników politycznych przez funkcjonariuszy i żołnierzy UB, KBW, WOP i WP. Potrzeba uwiarygodniania się przez komunistów w oczach społeczeństwa polskiego, ale także na arenie międzynarodowej jako jedynej, uznanej społecznie władzy spowodowała, iż rozprawienie się z przeciwnikami politycznymi przy użyciu siły stało się niemożliwe. Dogodnym rozwiązaniem okazało się stworzenie całkowicie kontrolowanego wojskowego wymiaru sprawiedliwości. Jego działalność posłużyła do zalegalizowania procederu eliminacji ze społeczeństwa obywateli o odmiennych poglądach politycznych, co $\mathrm{w}$ ujęciu propagandowym przyczyniło się do „dalszej stabilizacji” $i$ „normalizacji” sytuacji w kraju.

Przestępczy charakter działalności funkcjonariuszy UB, prokuratorów oraz sędziów, którzy uczestniczyli w wydawaniu wyroków z pogwałceniem podówczas obowiązującego prawa i wbrew ustaleniom faktycznym, nie następuje.

Udowodnienie, że oskarżenie, proces i skazanie konkretnej osoby nastąpiło z przyczyn politycznych, jest niezwykle trudne. Najczęściej nie można również dowieść, iż członkowie składu orzekającego lub prokuratorzy wojskowi wiedzieli o nieprawidłowościach $\mathrm{w}$ postępowaniu przygotowawczym, np. o wymuszaniu zeznań, o naruszeniach prawa do obrony czy fałszowaniu dokumentów.

Odstąpienie od ścigania sprawców przestępstw sądowych, będących zbrodniami komunistycznymi, pozostaje $\mathrm{w}$ sprzeczności ze społecznym poczuciem sprawiedliwości i zasadami demokratycznego państwa prawa ${ }^{48}$. Celem państwa prawa powinno być ukaranie sprawców przestępstw, a okolicznością wykluczającą odpowiedzialność nie może być uznanie, że realizowali oni „ludowy wymiar sprawiedliwości", działając na zlecenie polityczne.

Obserwując prawne rewindykacje po transformacji ustrojowej w Polsce, łatwo skonstatować, że realizacja zasady sprawiedliwości w III Rzeczypospolitej dokonuje się niezwykle opieszale. Osądzenie i skazanie funkcjonariuszy państwowych, którzy naginając prawo, realizowali cele polityczne i w rzeczywistości chronili partykularne interesy PPR, a następnie PZPR, stanowi niewątpliwie konieczną formę rozliczenia się z przeszłością. Dopełnienie sprawiedliwości w tym zakresie mogłoby być także przestrogą dla przyszłych pokoleń, że nieprawość i niesprawiedliwość zawsze spotka się ze słuszną odpłatą. Zaniechanie tego procesu oznacza zgodę na polityzację wymiaru sprawiedliwości i uczynienie zeń domeny etatystycznego relatywizmu prawnego wyrażonego

48 Postulował to m.in. Witold Kulesza, wskazując, że czyny sędziów i prokuratorów stanowiły wstrząsające przykłady łamania elementarnych wolności i praw ludzkich. Więcej zob. W. Kulesza, op. cit., s. 507. 
w twierdzeniu, że „każde prawo stanowione przez władzę państwową, nawet gdyby było sprzeczne z podstawowymi wartościami, usprawiedliwia funkcjonariuszy państwowych" 49 .

\section{Bibliografia}

\section{Akty prawne}

Rozporządzenie Prezydenta RP z dnia 19 marca 1928 r. - Kodeks postępowania karnego (Dz.U. RP 1932, Nr 83, poz. 725).

Dekret PKWN z 23 IX 1944 r. prawo o ustroju sądów wojskowych i prokuratury wojskowej (Dz.U. 1944, Nr 6, poz. 29).

Dekret PKWN z 23 VI 1945 r. kodeks wojskowy postępowania karnego (Dz.U. 1945, Nr 36, poz. 216 z późn. zm.).

Kodeks karny z dnia 6 czerwca 1997 r. (Dz.U. 1997, Nr 88, poz. 553 z późn. zm.).

Ustawa z dnia 3 grudnia 1998 r. o odpowiedzialności dyscyplinarnej sędziów, którzy w latach 1944-1989 sprzeniewierzyli się niezawisłości sędziowskiej (Dz.U. 1999, Nr 1, poz. 1 z późn. zm.).

Ustawa z dnia 18 grudnia 1998 r. o Instytucie Pamięci Narodowej - Komisji Ścigania Zbrodni przeciwko Narodowi Polskiemu (Dz.U. 2014, poz. 1075).

\section{Orzecznictwo}

Uzasadnienie wyroku Sądu Garnizonowego z 18 IV 2003 r. w sprawie przeciwko Tadeuszowi W., sygn. akt 477/2002, nieopublikowany, cyt. za: L. Rączy, Zbrodnie sądowe sędziów i prokuratorów - wybrane zagadnienia odpowiedzialności karnej na podstawie ustawy o Instytucie Pamięci Narodowej - Komisji Ścigania Zbrodni przecizoko Narodowi Polskiemu, [w:] Zbrodnie przeszłości. Opracowania i materiały prokuratorów IPN, red. P. Piątek, t. 9, Warszawa 2006.

Wyrok SN Izba Wojskowa z 2 IV 2001 r. w sprawie Wacława K., sygn. akt WA 7/01, nieopublikowany, cyt. za: L. Rączy, Zbrodnie sądowe sędziów i prokuratorów - wybrane zagadnienia odpowiedzialności karnej na podstawie ustawy o Instytucie Pamięci Narodowej - Komisji Ścigania Zbrodni przeciwko Narodowi Polskiemu, [w:] Zbrodnie przesztości. Opracowania i materiaty prokuratorów IPN, red. P. Piątek, t. 9, Warszawa 2006.

49 Uzasadnienie wyroku Sądu Garnizonowego z 18 IV 2003 r. w sprawie przeciwko Tadeuszowi W., sygn. akt 477/2002, nieopublikowany, cyt. za: L. Rączy, op. cit., s. 15. 
Okólnik nr 26 z 30 X 1946 r. Departamentu Służby Sprawiedliwości Ministerstwa Obrony Narodowej cyt. za: Skazani na karę śmierci przez WSR w Rzeszowie 1946-1954, red. T. Bereza, P. Chmielowiec, Rzeszów 2004.

Uzasadnienie wyroku Sądu Garnizonowego w Warszawie z 18 IV 2003 r. w sprawie przeciwko Tadeuszowi W., sygn. akt 477/2002, nieopublikowany, cyt. za: L. Rączy, Zbrodnie sądowe sędziów i prokuratorów - wybrane zagadnienia odpowiedzialności karnej na podstawie ustawy o Instytucie Pamięci Narodowej - Komisji Ścigania Zbrodni przeciwko Narodowi Polskiemu, [w:] Zbrodnie przeszłości. Opracowania i materiały prokuratorów IPN, red. P. Piątek, t. 9, Warszawa 2006.

Wyrok Sądu Apelacyjnego w Warszawie z 10 II 2005 r., sygn. akt II AKa 440/04, OSA 2005/9/67, LEX 146670.

Wyrok WSG we Wrocławiu z 14 X 2002 r. w sprawie przeciwko Jerzemu M., sygn. akt Sg 666/01, nieopublikowany, cyt. za: L. Rączy, Zbrodnie sądowe sędziów i prokuratorów - wybrane zagadnienia odpowiedzialności karnej na podstawie ustawy o Instytucie Pamięci Narodowej - Komisji Ścigania Zbrodni przeciwko Narodowi Polskiemu, [w:] Zbrodnie przeszłości. Opracowania i materiały prokuratorów IPN, red. P. Piątek, t. 9, Warszawa 2006.

Uzasadnienie wyroku Sądu Apelacyjnego w Warszawie z 10 II 2005 r. sygn. akt II Aka 440/04, OSA 2005/9/67, LEX 146670.

Wyrok SA w Warszawie z 10 II 2005 r., sygn. akt II Aka 440/04, cyt. za: R. Kopydłowski, Analiza definicji zbrodni komunistycznej, [w:] Zbrodnie przeszłości. Opracowania i materiaty prokuratorów IPN, t. 4: Ściganie, red. R. Ignatiew, A. Kura, Warszawa 2012.

Wyrok Sądu Apelacyjnego w Katowicach z 28 II 2003 r., sygn. akt II Aka 298/02, KZS 2006/11/97, LEX 228004;

Wyrok Sądu Apelacyjnego w Warszawie z 10 II 2005 r., sygn. akt II Aka 440/04, OSA 2005/9/67, LEX 146670.

Postanowienie SN z 5 VII 2005, sygn. akt WZ 13/05, OSNKW 2005/10/98; L. Rączy, Zbrodnie sądowe sędziów i prokuratorów - wybrane zagadnienia odpowiedzialności karnej na podstawie ustawy o Instytucie Pamięci Narodowej - Komisji Ścigania Zbrodni przeciwko Narodowi Polskiemu, [w:] Zbrodnie przeszłości. Opracowania i materiały prokuratorów IPN, red. P. Piątek, t. 9, Warszawa 2006.

\section{Literatura}

Balbus T., Nawrocki Z., Ludzie Różańskiego. Pion śledczy rzeszowskiego UB w 1948 roku, „Studia Rzeszowskie” 2002, t. 9.

Bedyński K., Sądowa represja o charakterze politycznym wobec funkcjonariuszy więziennych w latach 1944-1956, [w:] Przestępstwa sędziów i prokuratorów w Polsce 1944-1956, red. W. Kulesza, A. Rzepliński, Warszawa 2000.

Drogoń A., Prokuratura w okresie kształtowania ustroju po II wojnie światowej w Polsce (1944-1950) - podstawy prawne, polityka, praktyka, [w:] Wielokulturowość 
polskiego pogranicza. Ludzie - idee - prawo, red. A. Lityński, P. Fiedorczyk, Białystok 2003.

Feldman J., Nadzór prokuratora wojskowego nad postępowaniem przygotowawczym, „Wojskowy Przegląd Prawniczy" 1954, R. 27, nr 3 (39).

Kopydłowski R., Analiza definicji zbrodni komunistycznej, [w:] Zbrodnie przeszłości. Opracowania i materiaty prokuratorów IPN, t. 4, Ściganie, red. R. Ignatiew, A. Kura, Warszawa 2012.

Kopydłowski R., Pojęcie zbrodni komunistycznej z uwzględnieniem problemu czynu zabronionego popetnionego przez funkcjonariusza państwa komunistycznego, niemotywowanego szczególnym zamiarem, np. represji z motywów politycznych (artykuł polemiczny), [w:] Zbrodnie przeszłości. Opracowania i materiały prokuratorów IPN, red. P. Piątek, t. 9, Warszawa 2006.

Kulesza W., Odpowiedzialność karna sędziów i prokuratorów za zbrodnię sądowa, [w:] Przestępstwa sędziów i prokuratorów w Polsce w latach 1944-1956, red. W. Kulesza, A. Rzepliński, Warszawa 2000.

Leszczyńska Z., Procesy sądowe w latach 1944-1956 wobec członków organizacji niepodległościowych na Lubelszczyźnie, [w:] Przestępstwa sędziów i prokuratorów w Polsce w latach 1944-1956, red. W. Kulesza, A. Rzepliński, Warszawa 2000.

Muszkat M., Zapolski-Downar H., Podstawowe zasady nowego kodeksu wojskowego postępowania karnego, „Wojskowy Przegląd Prawniczy” 1945, nr 1.

Nawrocki Z., Zamiast wolności. UB na Rzeszowszczyźnie 1944-1949, Rzeszów 1998.

Piątek P., Glosa do wyroku Sądu Apelacyjnego w Katowicach z dnia 28 lutego 2003 roku, sygn. akt II Aka 298/02 (dotyczy pojęcia zbrodni komunistycznej), [w:] Zbrodnie przeszłości. Opracowania i materiały prokuratorów IPN, red. P. Piątek, t. 9, Warszawa 2006.

Rączy L., Zbrodnie sądowe sędziów i prokuratorów - wybrane zagadnienia odpowiedzialności karnej na podstawie ustawy o Instytucie Pamięci Narodowej - Komisji Ścigania Zbrodni przeciwko Narodowi Polskiemu, [w:] Zbrodnie przeszłości. Opracowania i materiały prokuratorów IPN, red. P. Piątek, t. 9, Warszawa 2006.

Skrypt wykładów służby śledczej w Centrum Wyszkolenia MO, Słupsk 1947.

Szwagrzyk K., Prawnicy czasu bezprawia. Sędziowie i prokuratorzy wojskowi w Polsce 1944-1956, Kraków-Wrocław 2005.

Wędrychowska E. L., Stabilność zawodu sędziego w świetle ostatnich zmian przepisów prawa o ustroju sądów powszechnych, „Prokuratura i Prawo” 2000, nr 1 (89), LEX 24022/1.

Wituszko D., Wpływ immunitetu na odpowiedzialność karna sędziów i prokuratorów za zbrodnie sadowe $z$ uwzględnieniem aspektów praktycznych wynikajacych z prowadzonych postępowań, [w:] Zbrodnie przeszłości. Studia i materiały prokuratorów IPN, red. P. Piątek, t. 9, Warszawa 2006. 